J Arid Land (2013) 5(3): 310-323

doi: $10.1007 / \mathrm{s} 40333-013-0171-1$

jal.xjegi.com; www.springer.com/40333

\title{
Diaspore characteristics and ecological adaptation of Bromus tectorum L. from different distribution regions
}

\author{
YaoBin LIU ${ }^{1,2}$, YuanMing ZHANG ${ }^{1 *}$, Robert S NOWAK ${ }^{3}$, Liliya DIMEYEVA ${ }^{4}$ \\ ${ }^{1}$ Key Laboratory of Biogeography and Bioresource in Arid Land, Xinjiang Institute of Ecology and Geography, Chinese Academy of \\ Sciences, Urumqi 830011, China; \\ ${ }^{2}$ Graduate University of Chinese Academy of Sciences, Beijing 100049, China; \\ ${ }^{3}$ Department of Natural Resources and Environmental Science, University of Nevada-Reno, Reno, Nevada 89557, USA; \\ ${ }^{4}$ Institute of Botany and Phytointroduction, Almaty 050040, Kazakhstan
}

\begin{abstract}
The invasion of nonnative plants is considered one of the main threats to the structure and function of North American ecosystems. Moreover, they can alter ecosystem processes and reduce biodiversity. In arid and semi-arid region of North America, the species of European annual grass Bromus tectorum L. is an outstanding example of these problems, which not only increase the fire density and change the fire regime, but replace native communities. Therefore, there are amount of researches on $B$. tectorum, including resource acquisition, water use efficiency and growth. Whereas the relevant research on the morphology of diaspore is scare. Diaspores have a fundamental role in seed germination and seedling establishment. Besides, as an important link between different generations, diaspores have a vital significance on individual reproduction and population extension. Hence, diaspores under selection for studying have an important implication. This study compares differences in seed morphology for Bromus tectorum collected from the United States, Kazakhstan, and Xinjiang of China. The following indices of $B$. tectorum diaspores were analyzed: size, thickness of covering layers, and micromorphological characteristics of the base, middle and transition area of diaspores as well as of the awn. Micromorphology of the lemma and the cross-section of the diaspore were observed by scanning electron microscopy. Results showed that thickness of the lemma and the palea of diaspores from $B$. tectorum-infested grasslands in the United States were reduced $(P<0.05)$, likely because of environmental influences. This reduction facilitated the germination of diaspores and lowered the resistance of $B$. tectorum to adverse environmental conditions. The length of the awn also increased significantly $(P<0.05)$, which helped in dispersal and anchoring of diaspores. Therefore, $B$. tectorum adapted ecologically to its new environment in the United States by strengthening its establishment ability. However, the defense capability of $B$. tectorum decreased. These results fit the evolution of increased competitive ability hypothesis (EICA) of invasive species. Analysis of various cells on the lemma revealed that prickle densities and collapsed, long epidermal cells were easily influenced by environmental factors such as temperature and moisture because of the physiologic function of these structures on silicon accumulation. However, the form and the position of silica cells, which were not greatly influenced by environmental factors, might be genetically controlled. Studying these structures at the microscopic level helps define the relationship between the diaspore and its environment. This study has a reference value for future studies on $B$. tectorum.
\end{abstract}

Keywords: Bromus tectorum; diaspore; micromorphology; lemma; Kazakhstan; United States; Xinjiang of China

Citation: YaoBin LIU, YuanMing ZHANG, Robert S NOWAK, Liliya DIMEYEVA. 2013. Diaspore characteristics and ecological adaptation of Bromus tectorum L. from different distribution regions. Journal of Arid Land, 5(3): 310-323.

As one main component of global change, biological invasion is considered to be one of the primary threats to rare and endangered species, biodiversity, as well as the integrity and function of native ecosystems

*Corresponding author: YuanMing ZHANG (E-mail: zhangym@ms.xjb.ac.cn)

Received 2012-11-16; revised 2013-01-28; accepted 2013-01-31

(C) Xinjiang Institute of Ecology and Geography, Chinese Academy of Sciences, Science Press and Springer-Verlag Berlin Heidelberg 2013 
worldwide. In addition, biological invasion has brought tremendous economic loss. According to related researches, some of the invasive species can alter the ecological processes, for example, Bromus tectorum can change the fire regimes (Blossey and Notzold, 1995; Drake, 2004).

Bromus tectorum L. (Cheatgrass) is an annual grass native to Central Asia and currently found in other parts of the world, including Europe and North America. B. tectorum has become one of the most problematic invasive species in North America since its introduction in the late $19^{\text {th }}$ century (Klemmedson and Smith, 1964).

A number of studies on B. tectorum have been conducted, with focus on topics such as its control and management, regulation of seed dormancy and germination, physiological ecology, and resource acquisition of the plant (Wicks, 1984; Caldwell et al., 1985; Challaiah et al., 1986; Meyer et al., 1997; Meyer and Allen, 1999). For example, Melgoza and Nowak (1991) indicated that the root system of cheatgrass rapidly occupies underground space and competes with other species for resources, which reduces the root systems of other species. Other studies showed that B. tectorum exhibits a strong resistance to drought and that the root system of the grass effectively extracts water from the soil (Hull, 1963). Corresponding research revealed that rapid dry-matter accumulation of the whole leaf parallels a rapid increase in the leaf area (Zhu, 1992).

B. tectorum produces diaspores and forms a seed bank in the soil, and in drier habitats, the soil seed bank will sustain for a long time (Beckstead, 2007). In addition, diaspore size significantly influences seedling survival. These characteristics could be inherited (Leger et al., 2009). Meyer et al. (1999) verified that phenological regulation of seed germination is an important part of the life-history strategy of this invasive plant. Rice et al. (2001) demonstrated that aged seeds exhibit germination delays that reduce plant growth and decrease final biomass when plants are grown with competition. Diaspores are among the most important reproductive organs of seed plants and are produced during an important stage of the plant life cycle. Diaspores act as a link between different gen- erations; this role of the diaspore has vital significance on individual reproduction and population extension (Zhang et al., 2006; Yang et al., 2007).

Numerous studies showed that characteristics of appendages on grass diaspores are conservative (Xie et al., 2002), which lead to their important value in taxonomic classification (Decker, 1964; Kumar and Rangaswamy, 1984; Jacobs, 2001; Ortúñez and de la Fuente, 2010; Zhang et al., 2010). Seed longevity, seed dispersal, and seed germination are closely related to diaspore appendages such as the awn, lemma, palea, and callus (Chambers, 1995). Appendages also determine the vigor and water absorption of diaspores to a certain extent. Kaufman et al. (1972) found that micromorphological characteristics provide mechanical support for diaspores and protect diaspores from insects and other predators. In addition, the micro-structural features of diaspores showed ecological adaptability in special environments (Ma et al., 2003). Relevant studies revealed that the different micromorphological characteristics of diaspores resulted from their long adaptation to different ecological environments. Peart (1984) indicated that variation in micromorphological diaspore characteristics such as the number of papillary short cells, prickle hairs, and macrohairs of the lemma reflect the effective adaptation of plants to their environments at each stage of their life cycle (Shu et al., 1990; Xie et al., 2002). The size variations of diaspores are related to the light, temperature, rainfall, altitude and latitude of the distribution area, and the interaction and interplay among these factors are common. Besides, the variations resulted from the complex terrain and the weather type variety complicacy; hence this kind of variation is adaptation to the complicated environment (Zhou, 2003). Although most studies on the invasive species $B$. tectorum are focused on seed germination and dormancy characteristics (Evans et al., 1987), the relationship between micromorphological characteristics of diaspores and their ecological adaptation has not been reported.

Thus, this study examines the micromorphological characteristics of $B$. tectorum diaspores from different regions using scanning electron microscope (SEM). This study has the following objectives: (1) to inves- 
tigate how morphological characteristics of diaspores differ among different environments; (2) to examine whether B. tectorum diaspores possess mechanisms of adaptation to environmental factors; and (3) to provide knowledge on ecological adaptation of invasive species from the perspective of micromorphological characteristics of diaspores.

\section{Materials and methods}

Table 1 shows some information about the collection sites of Bromus tectorum. All diaspores used in this study were obtained from the United States (A), Kazakhstan (K), and Xinjiang of China (X). Forty populations were collected from 8 sites (Fig. 1). At each site, we choose five $2-\mathrm{m}^{2}$ quadrat, in each quadrat, diaspores of B. tectorum $\mathrm{L}$. were collected randomly from each of 30 individual plants from May to June 2012 (voucher specimens were stored at the Herbarium of Xinjiang Institute of Ecology and Geography, Chinese Academy of Sciences (XJBI)).

Table 1 Geographic coordinates of collection sites

\begin{tabular}{|c|c|c|c|c|c|}
\hline \multirow{2}{*}{ Number } & \multirow{2}{*}{ Collection site } & \multicolumn{3}{|c|}{ Geographic location } & \multirow{2}{*}{ Date of collection } \\
\hline & & Longitude & Latitude & Altitude (m) & \\
\hline 1 & Great Basin (A) & $116^{\circ} 27.40^{\prime} \mathrm{W}$ & $38^{\circ} 47.40^{\prime} \mathrm{N}$ & 1,500 & 09 May 2012 \\
\hline 2 & Gongliu (X1) & $81^{\circ} 45.62^{\prime} \mathrm{E}$ & $43^{\circ} 41.66^{\prime} \mathrm{N}$ & 780 & 05 June 2012 \\
\hline 3 & Kuitun (X2) & $82^{\circ} 15.90^{\prime} \mathrm{E}$ & $43^{\circ} 25.85^{\prime} \mathrm{N}$ & 592 & 05 June 2012 \\
\hline 4 & Yining (X3) & $81^{\circ} 32.43^{\prime} \mathrm{E}$ & $44^{\circ} 4.07^{\prime} \mathrm{N}$ & 604 & 05 June 2012 \\
\hline 5 & Zhaisan (K1) & $76^{\circ} 16.97^{\prime} \mathrm{E}$ & $43^{\circ} 24.44^{\prime} \mathrm{N}$ & 680 & 02 July 2012 \\
\hline 6 & Akshiy (K2) & $76^{\circ} 20.63^{\prime} \mathrm{E}$ & $43^{\circ} 53.53^{\prime} \mathrm{N}$ & 570 & 02 July 2012 \\
\hline 7 & Taukum Desert (K3) & $76^{\circ} 14.22^{\prime} \mathrm{E}$ & $44^{\circ} 12.56^{\prime} \mathrm{N}$ & 515 & 02 July 2012 \\
\hline 8 & Taukum Desert (K4) & $75^{\circ} 21.50^{\prime} \mathrm{E}$ & $44^{\circ} 40.64^{\prime} \mathrm{N}$ & 380 & 02 July 2012 \\
\hline
\end{tabular}

\subsection{Morphological characteristics of diaspores}

A total of 50 fully matured diaspores were chosen separately from each of the 8 different regions. Length, width, and thickness of each diaspore were measured with a vernier caliper. Exactly 20 complete diaspores from different regions were then weighed. The awn of each diaspore was clipped, and de-awned diaspores were then re-weighed. The weight ratio between the awn and the complete diaspore was calculated. All measurements were repeated 8 times.

\subsection{Methods of micromorphology}

Complete diaspores used for scanning electron microscope (SEM) were selected randomly under a binocular microscope. Selected diaspores were washed with distilled water and then cleaned using an ultrasound for $20 \mathrm{~min}$. A total of 20 diaspores were cut transversely; five or more fully matured diaspores of each collection were chosen. Transverse sections and diaspores were mounted on aluminum stubs with double-sided adhesive tape. Samples were coated with approximately $20 \mathrm{~nm}$ of gold and were then observed by SEM (Zeiss Supra 55VP, Germany) at an acceleration voltage of $10 \mathrm{KeV}$. Thickness of covering layers was measured with Photoshop software (Adobe Systems, USA). Five parts of diaspores were photographed: base, central region, transition area between awn and lemma, transverse section, and awn. Terminology for epidermal features of the diaspore follows Metcalfe (1960) and Ellis (1979). Cell density refers to number of cells per square millimeter.

Awns arise near the middle of the back of a lemma. Five different views of the central awn were selected, observed, and photographed. Densities of stomata and microhairs on the awn were then computed.

Five views of each of the base, middle, and transition area between the awn and the lemma were selected and photographed. The numbers of hooded short cells (hooks), prickles, papillary short cells, silica cells, long epidermal cells, and stomata per square millimeter were computed. The lengths of prickles and macrohairs were measured at the same magnification level. 


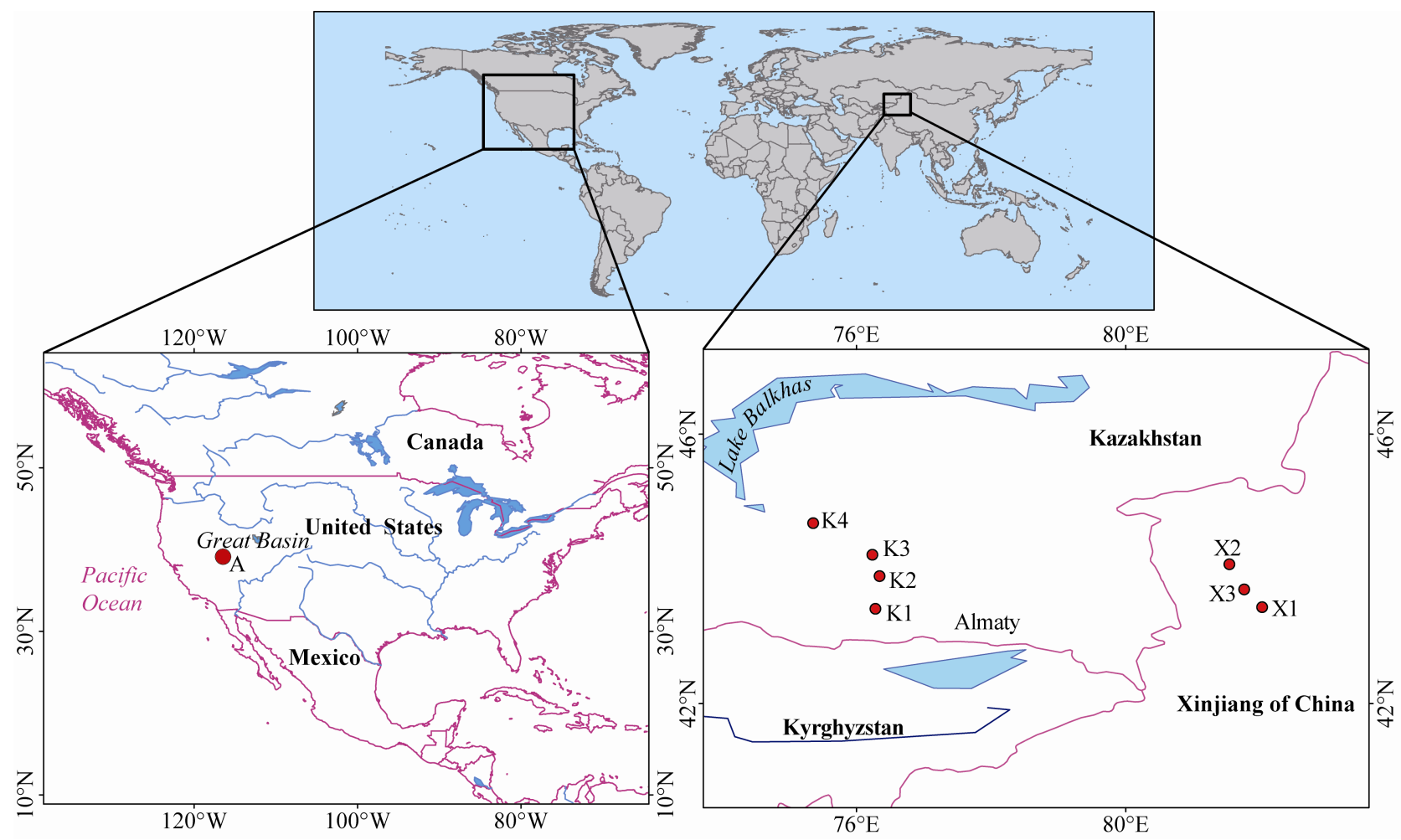

Fig. 1 The distribution map of collection sites of Bromus tectorum in study area

\subsection{Data analysis}

The units of the length, width and depth of diaspores from different regions were unified, and then the differences of diaspore sizes were analyzed by ANOVA in SPSS (SPSS Inc., Illinois, USA). And the least significant difference (LSD) was employed for multiple comparison. In terms of the scanning electron microscope, we first used the Photoshop software to count the number of each type of cells, and then calculated the area of each graph according to the scale. With the combination of the number of cells and the area of graph, the cell density can be computed. The ANOVA and LSD were used for variation analyses and multiple comparisons. The average values were used for plotting with Origin 8.0 (OriginLab Corp., USA).

\section{Results}

\subsection{Size of diaspores from different regions}

The B. tectorum diaspores from the Great Basin of the United States (A) are significantly longer than those from Central Asia locations. The diaspores from A are
1.4 times longer than those from K1 (Fig. 2a). Diaspores from $\mathrm{A}$ and $\mathrm{K} 4$ are wider than those from $\mathrm{X} 2$, $\mathrm{X} 3, \mathrm{~K} 1$, and $\mathrm{K} 3(P<0.05)$. No significant differences are shown between $\mathrm{X} 1$ and $\mathrm{K} 2(P>0.05)$, as well as among X2, X3, and $\mathrm{K} 1(P>0.05)$ (Fig. 2b). The diaspores from $\mathrm{K} 2$ and $\mathrm{K} 4$ are significantly thicker than those from X2, X3, and $\mathrm{K} 1 \quad(P<0.05)$ (Fig. 2c). No significant differences among the other regions are shown.

\subsection{Thickness of the covering layer of diaspores from different regions}

The layers that cover a diaspore consist of the lemma, palea, pericarp, and testa. Figure 3 presents SEM cross-sections of diaspores. Lemmas from $\mathrm{K} 3$ and $\mathrm{K} 4$ are thicker than those from $\mathrm{A}, \mathrm{X} 1, \mathrm{X} 2, \mathrm{X} 3$, and $\mathrm{K} 2$ (Fig. 4a). The palea from $\mathrm{K} 4$ is the thickest, and that from $A$ is the thinnest (Fig. $4 b$ ). The testa and pericarp from X3 are the thickest, reaching $19 \mu \mathrm{m}$. Figure $3 \mathrm{c}$ indicates no significant difference between $\mathrm{X} 2$ and $\mathrm{K} 3$. The testa and the pericarp from K1 are the thinnest, whereas the testa and pericarp from X3 are approximately 1.36 times thicker than those from $\mathrm{K} 1$. 


\subsection{Micromorphological characteristics of the le-} mma

\subsubsection{Basal part of the lemma}

Three different types of cells (PR, HSC, and SC) on the basal part of the lemma were analyzed. Figure 5 shows the micromorphology of the basal part of the lemma, and Fig. 6 shows the density of different types of cells on the lemma base.

SC density on the lemma base varies greatly among the different regions; and that from K4 (to 393 $\mathrm{Num} / \mathrm{mm}^{2}$ ) is higher than that from other regions. No significant differences are indicated among $\mathrm{K} 1, \mathrm{~K} 2$,
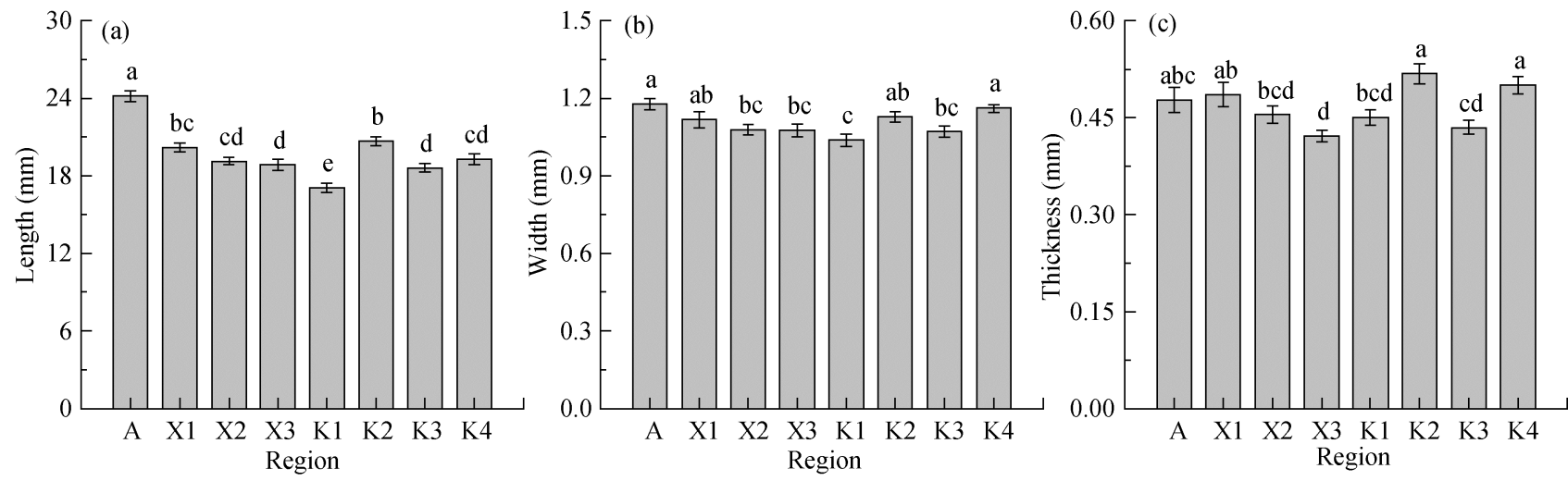

Fig. 2 The length (a), width (b), and thickness (c) of $B$. tectorum diaspores from different regions (mean $\pm S D$ ). Different letters indicate significant difference among regions $(n=50, P<0.05)$.
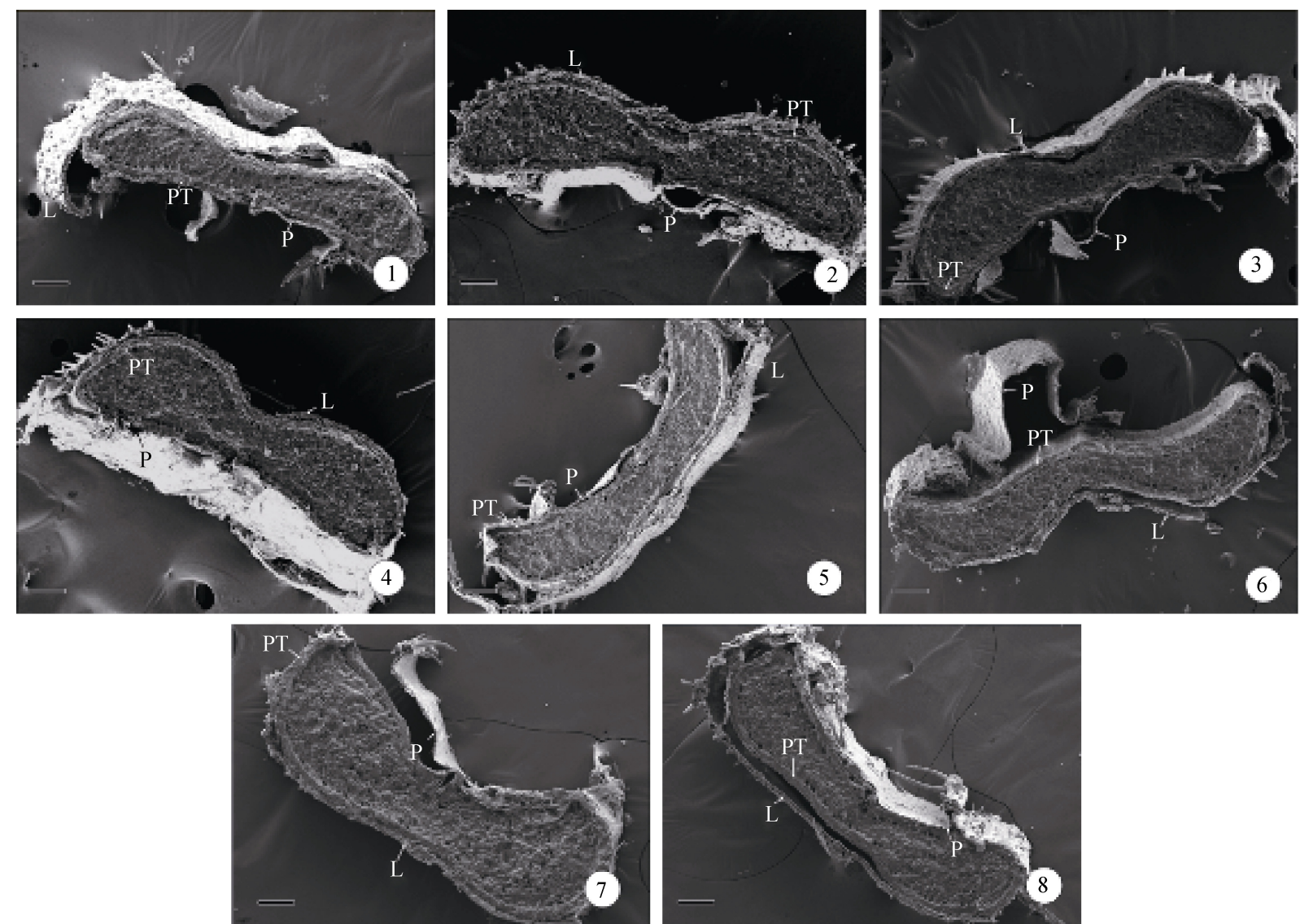

Fig. 3 Micromorphological characteristics of the cross-sections of the diaspores (scale=100 $\mu \mathrm{m}$ ).1,Great Basin (A); 2,Gongliu (X1); 3, Kuitun (X2); 4, Yining (X3); 5, Zhaisan (K1); 6, Akshiy (K2); 7, Taukum Desert (K3); 8, Taukum Desert (K4). The photo numbers from 1-8 in Figs 5, 7, 9, 11 are as same as in Fig. 3. Abbreviations: P, palea; L, lemma; PT, pericarp and testa. 

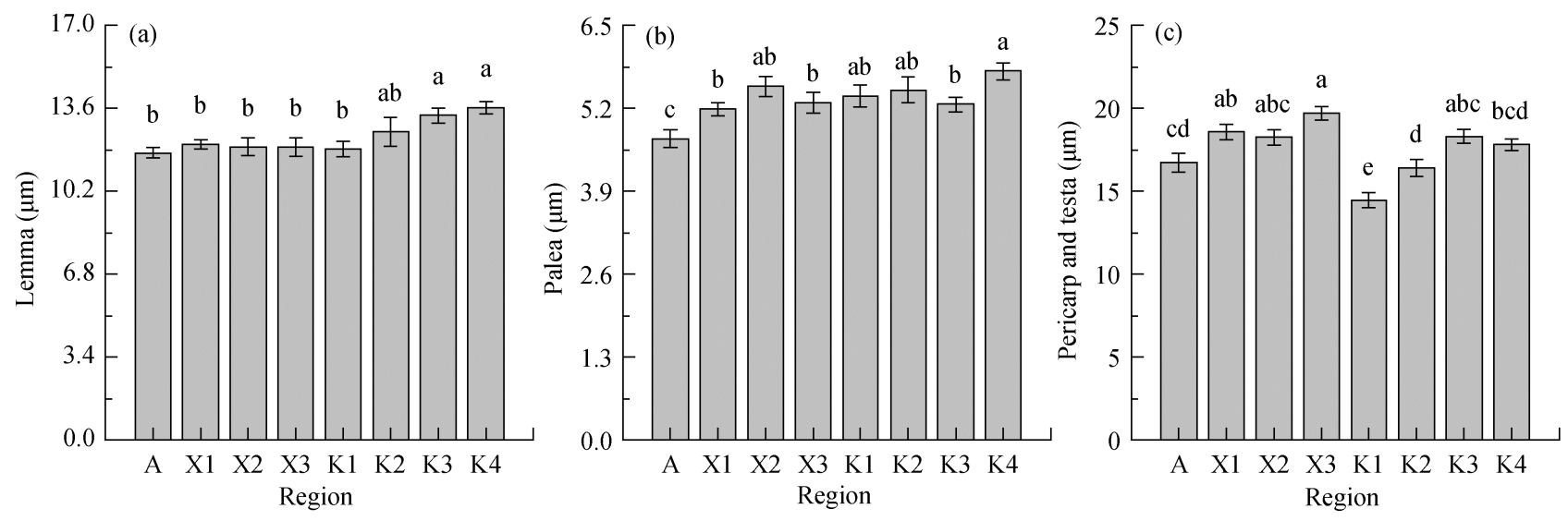

Fig. 4 Thickness of layers that cover diaspores: lemma (a), palea (b), and testa and pericarp (c)

and $\mathrm{X} 1(P>0.05)$, as well as among $\mathrm{A}, \mathrm{X} 2, \mathrm{X} 4$, and $\mathrm{K} 3$ $(P>0.05)$. SC density on the lemma base from $\mathrm{X} 2$ is the lowest, with only $128 \mathrm{Num} / \mathrm{mm}^{2}$ (Fig. 6a).

HSC densities on the basal part of the lemma from $\mathrm{X} 1$ and $\mathrm{X} 2$ are 2,822 and 2,683 Num/ $/ \mathrm{mm}^{2}$, respectively (Fig. 6b). No significant differences occur among X3, K1, and K2 $(P>0.05)$, between A and K2 $(P>0.05)$, and among A, K3, and K4 $(P>0.05)$. HSC density on the lemma base from $\mathrm{X} 1$ is 1.63 times higher than that from K4.

PR densities on the lemma base from A and $\mathrm{K} 1$ are higher than those from other regions. No significant difference occurs among X1, K2, and K4. PR density on the lemma base from X3 is $64 \mathrm{Num} / \mathrm{mm}^{2}$, which is the smallest among all lemmas from the different regions. PR densities on the lemma base from $\mathrm{K} 1$ and $\mathrm{A}$
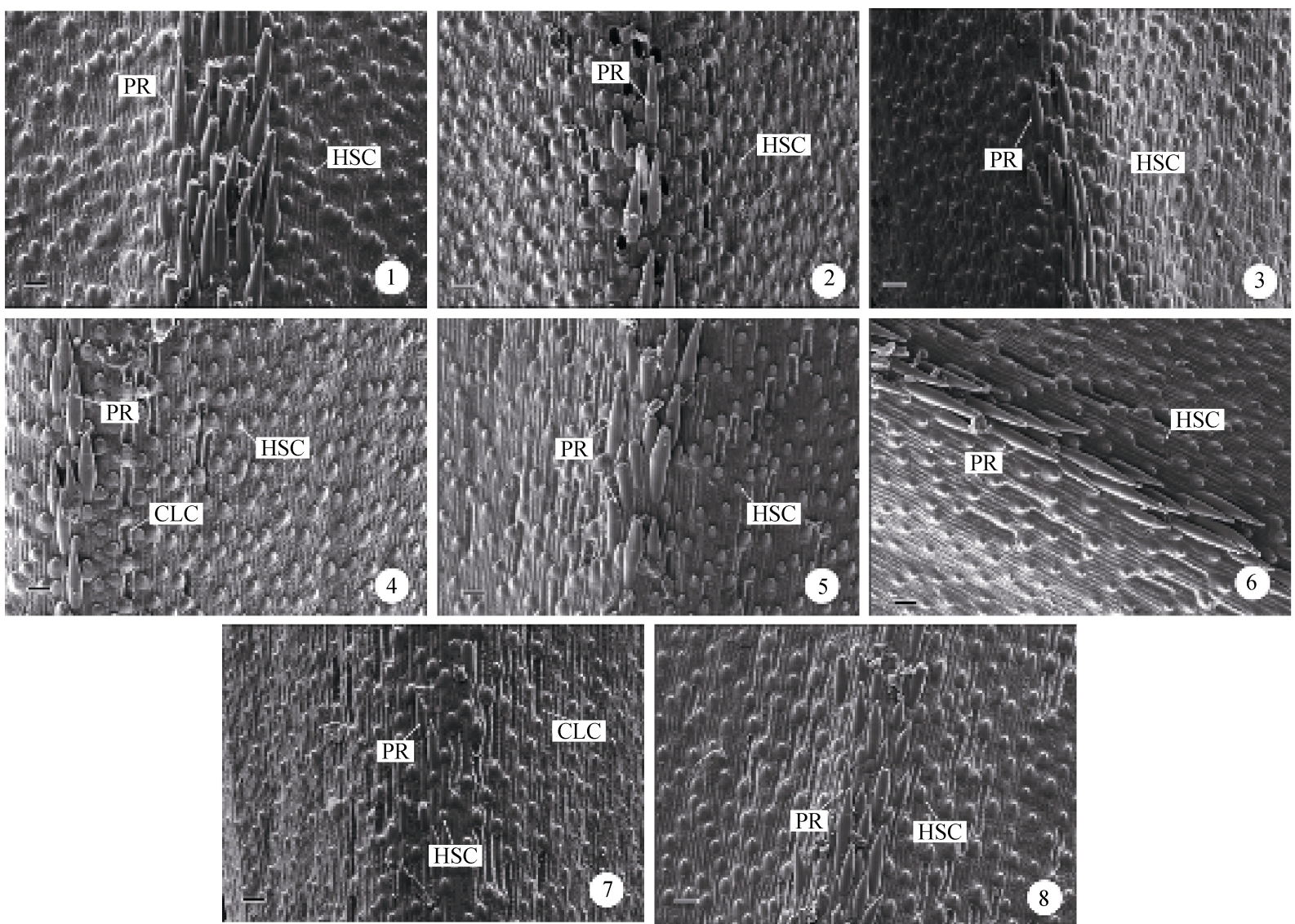

Fig. 5 Micromorphological characteristics on the basal part of the lemma (scale=20 $\mu \mathrm{m}$ ). Abbreviations: PR, prickle; HSC, hooked short cell; CLC, collapsed long epidermal cell. 

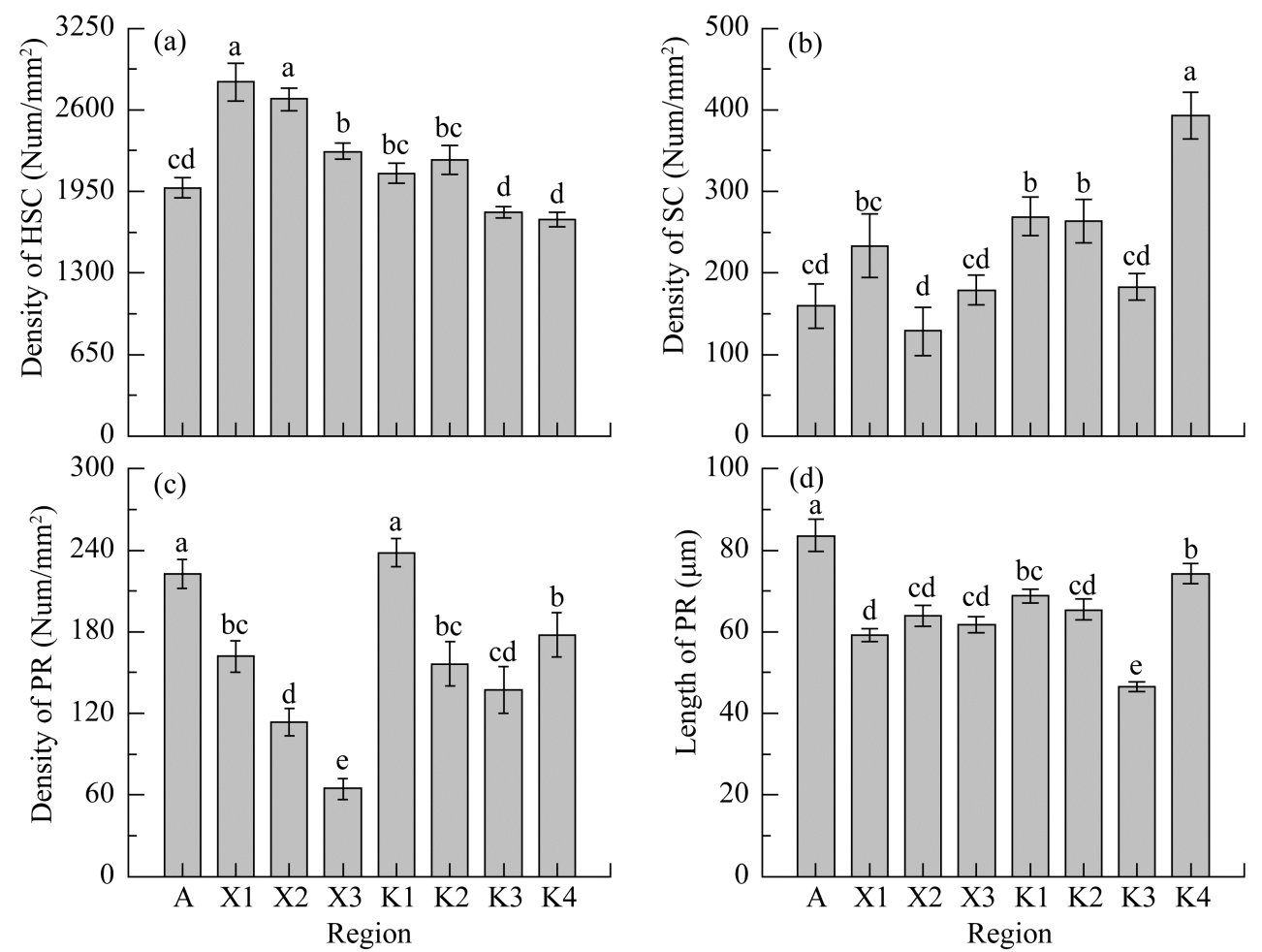

Fig. 6 The length and density of different types of cells on the basal part of the lemma. Abbreviations: HSC, hooked short cell; SC, silica cell; PR, prickle.

are respectively about 3.69 times and 3.45 times as high as that from X3 (Fig. 6c).

The length of the PR on the lemma base of the diaspore from $\mathrm{A}$ is about $83 \mu \mathrm{m}$ and is significantly higher than that from Central Asia. No significant differences are indicated among $\mathrm{X} 1, \mathrm{X} 2, \mathrm{X} 3, \mathrm{~K} 1$, and $\mathrm{K} 2$ $(P>0.05)$, as well as between $\mathrm{X} 2$ and $\mathrm{K} 3(P>0.05)$. PR length on the lemma base from $\mathrm{X} 3$ is the shortest, approximately $46 \mu \mathrm{m}$ (Fig. 6d).

\subsubsection{Middle part of the lemma}

Figure 7 shows the micromorphological characteristics of the middle part of the lemma. The PSC of X1 achieves the highest density at $1,479 \mathrm{Num} / \mathrm{mm}^{2}$. No significant differences occur among $\mathrm{X} 2, \mathrm{X} 3$, and $\mathrm{K} 3$, as well as among $\mathrm{A}, \mathrm{X} 2, \mathrm{~K} 1$, and $\mathrm{K} 3(P>0.05)$. PSC density of the mid-lemma from $\mathrm{X} 1$ is 1.4 times higher than that from K2 (Fig. 8a).

CLC density of the mid-lemma from $\mathrm{K} 4$ is signifi cantly higher than that from other regions (Fig. 8b). No significant difference occurs among A, X1, X2, X3, $\mathrm{K} 1$, and $\mathrm{K} 2(P>0.05)$.

$\mathrm{SC}$ densities of the mid-lemma from $\mathrm{X} 1, \mathrm{~K} 3$, and $\mathrm{K} 4$ are higher than those from other regions. No sig- nificant differences occur among the upper regions $(P>0.05)$, as well as among $\mathrm{A}, \mathrm{X} 2, \mathrm{~K} 2, \mathrm{~K} 3$, and $\mathrm{K} 4$ $(P>0.05)$. SC density of the mid-lemma from X3 is the lowest, with only $235 \mathrm{Num} / \mathrm{mm}^{2}$ (Fig. 8c).

\subsubsection{Transition area of the lemma}

Figure 9 shows SEM images of the transition area of the lemma. SC density in the lemma transition area from K4 is significantly higher than that from other regions, whereas stomata density of $\mathrm{K} 4$ is the lowest among all regions (Figs. 10a, b). MH densities of the lemma transition area from $\mathrm{K} 3$ and $\mathrm{K} 4$ are higher than those from other regions (Figs. 10c, f). However, $\mathrm{MH}$ lengths of $\mathrm{K} 3$ and $\mathrm{K} 4$ are lower than those from other regions $(P<0.05)$. No significant differences in PSC densities occurred among $\mathrm{A}, \mathrm{X} 2, \mathrm{X} 3, \mathrm{~K} 1$, and $\mathrm{K} 2$ $(P>0.05)$, as well as between $\mathrm{K} 3$ and $\mathrm{K} 4(P<0.05)$ (Fig. 10d). Lengths of stomata in the lemma transition area from A are significantly longer than those from Central Asia (Fig. 10e).

\subsubsection{Characteristics of the awn}

Figure 11 presents the central awn SEM. Awn lengths of A are significantly longer than those from Central Asia. No significant differences occur between X1 and 

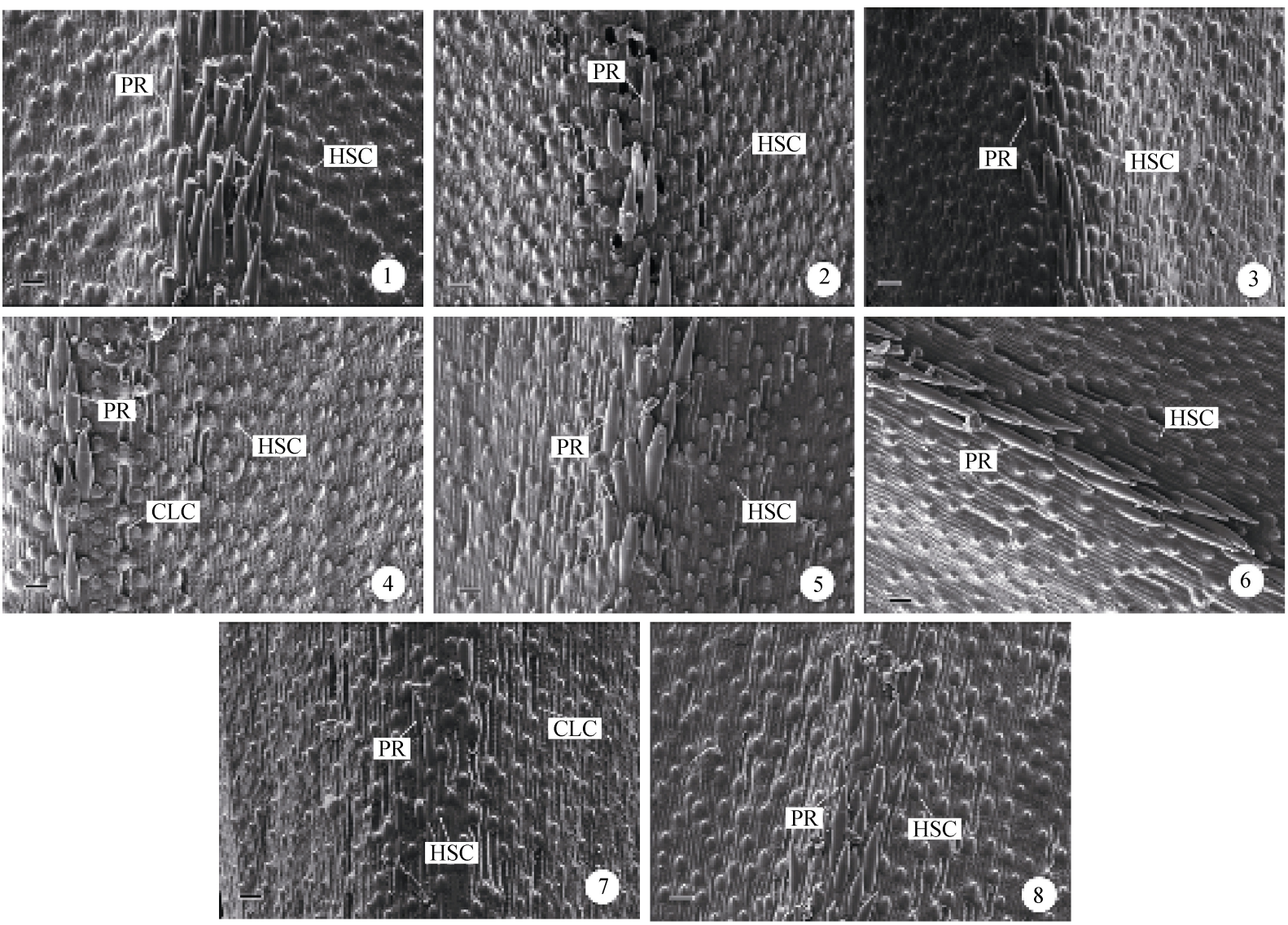

Fig. 7 Micromorphological characteristics of the middle part of the lemma (scale=10 $\mu \mathrm{m}$ ). Abbreviations: SC, silica cell; CLC, collapsed long epidermal cell; PR, prickle; PSC, papillary short cell.
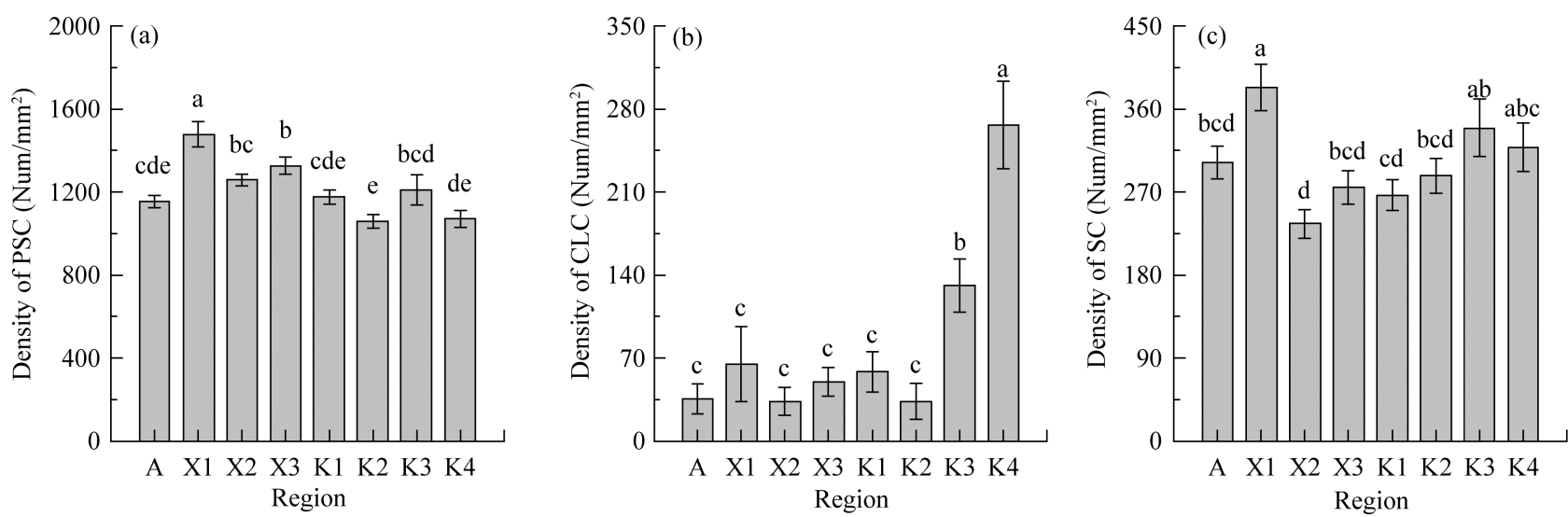

Fig. 8 Densities of different types of cells in the middle part of the lemma Abbreviations: PSC, papillary short cell; CLC, collapsed long epidermal cell; SC, silica cell.

$\mathrm{K} 2$, as well as among $\mathrm{X} 2, \mathrm{X} 3, \mathrm{~K} 2, \mathrm{~K} 3$, and $\mathrm{K} 4$ $(P>0.05)$. Awn length of $\mathrm{K} 1$ is the shortest at 0.905 $\mathrm{mm}$ (Fig. 12a). The awn length/diaspore length ratio was also calculated. Awn length/diaspore length of A is significantly greater than that from Central Asia. No significant differences occur in the awn length/dia- spore length ratio among $\mathrm{X} 1, \mathrm{X} 2$, and $\mathrm{K} 2$, as well as among $\mathrm{X} 2$, K1, K2, K3, and $\mathrm{K} 4$. The collection from $\mathrm{X} 3$ has the lowest awn length/diaspore length ratio (Fig. 12b). The ratio of awn weight/diaspore weight is the greatest for $\mathrm{A}$, with the awn weight/diaspore weight ratio of K2 a distant second (Fig. 12c). How- 

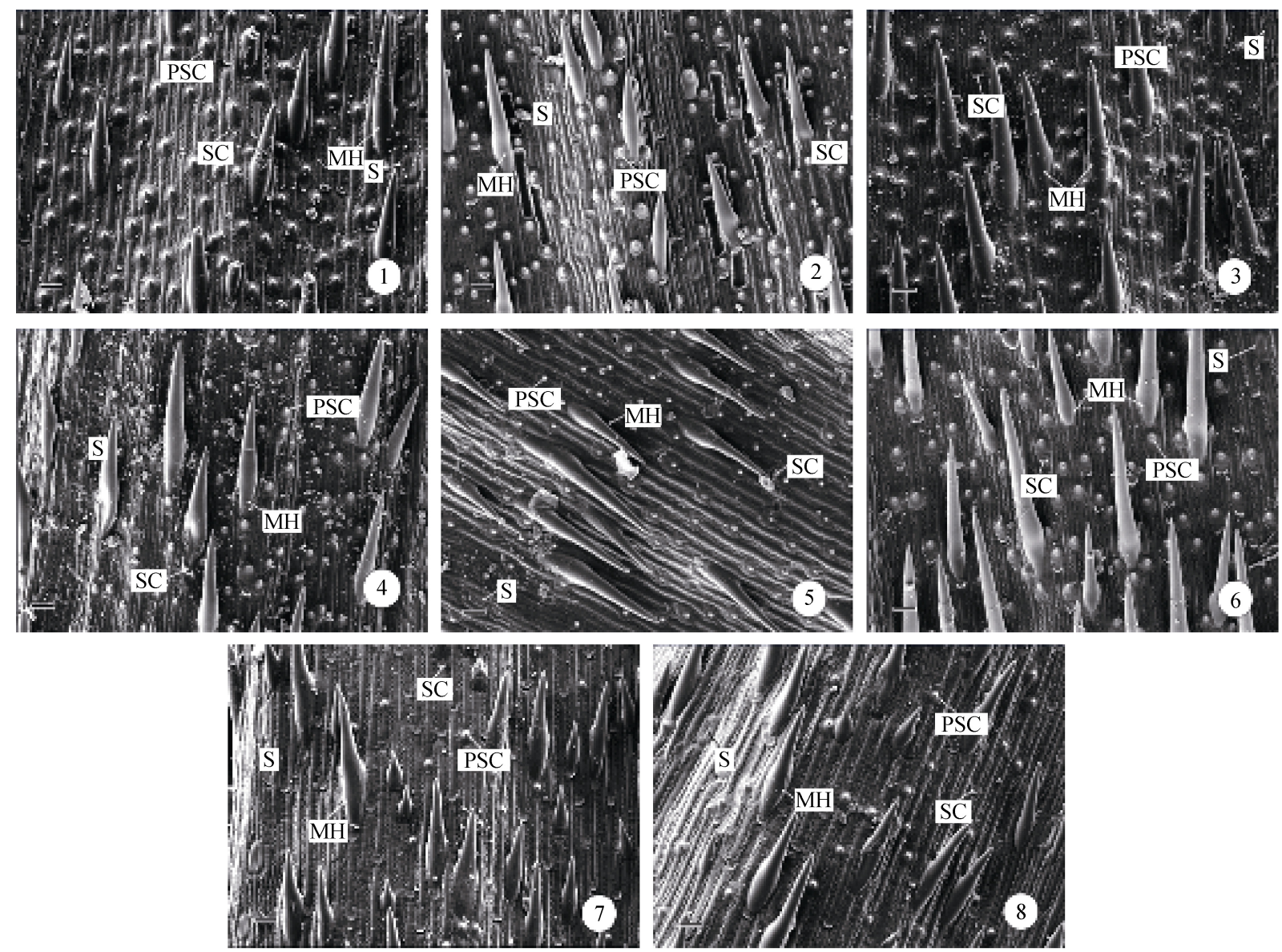

Fig. 9 Micromorphological characteristics of the transition area of the lemma (scale=20 $\mu \mathrm{m}$ ). Abbreviations: SC, silica cell; $\mathrm{MH}$, macrohair; PSC, papillary short cell; S, stomata.

ever, awn weight/diaspore weight ratios of other regions are not significantly different $(P>0.05)$ (Fig. 12c). Distinct differences in MiH density occur among the different regions. X1, X3, K1, and $\mathrm{K} 4$ are not significantly different $(P>0.05)$; similarly, no significant differences are indicated among $\mathrm{A}, \mathrm{X} 2, \mathrm{~K} 3$, and $\mathrm{K} 4$ $(P>0.05)$. Stomatal density of the central awn from the Great Basin is significantly smaller than that from Central Asia. However, the diaspores from the Great Basin are significantly longer than those from Central Asia. No significant difference in stomatas density occurs among diaspores from Central Asia $(P>0.05)$, although the stomata of diaspores from Central Asia varied in length. Stomatal length of X2 is significantly shorter than that from other Central Asian locations, but differences between $\mathrm{K} 3$ and $\mathrm{K} 4$, between $\mathrm{K} 3$ and $\mathrm{K} 1$, and among $\mathrm{K} 1, \mathrm{~K} 2$, and $\mathrm{X} 1$ are not significant $(P>0.05)$ (Figs. 12e, f).

\section{Discussion}

From Fig. 2, we can draw a conclusion that diaspores from the Great Basin were bigger than those from Central Asia. Large diaspores can supply more stored energy reserves during seed germination, which in turn can provide a competitive advantage (Black, 1958; Harper et al., 1970; Fenner, 1980), which might help to its further invasion.

Mature diaspores of $B$. tectorum are enclosed tightly within the lemma and palea, which together comprises the hull or husk of the grain. These protective layers that cover the diaspore influence the longevity of cheatgrass diaspores in the soil as well as seed dormancy. From Fig. 4, we can see that the thickness of these covering layers from $\mathrm{K} 3$ and $\mathrm{K} 4$ was higher than those from other regions. From this observation we can come to a conclusion that adapta- 

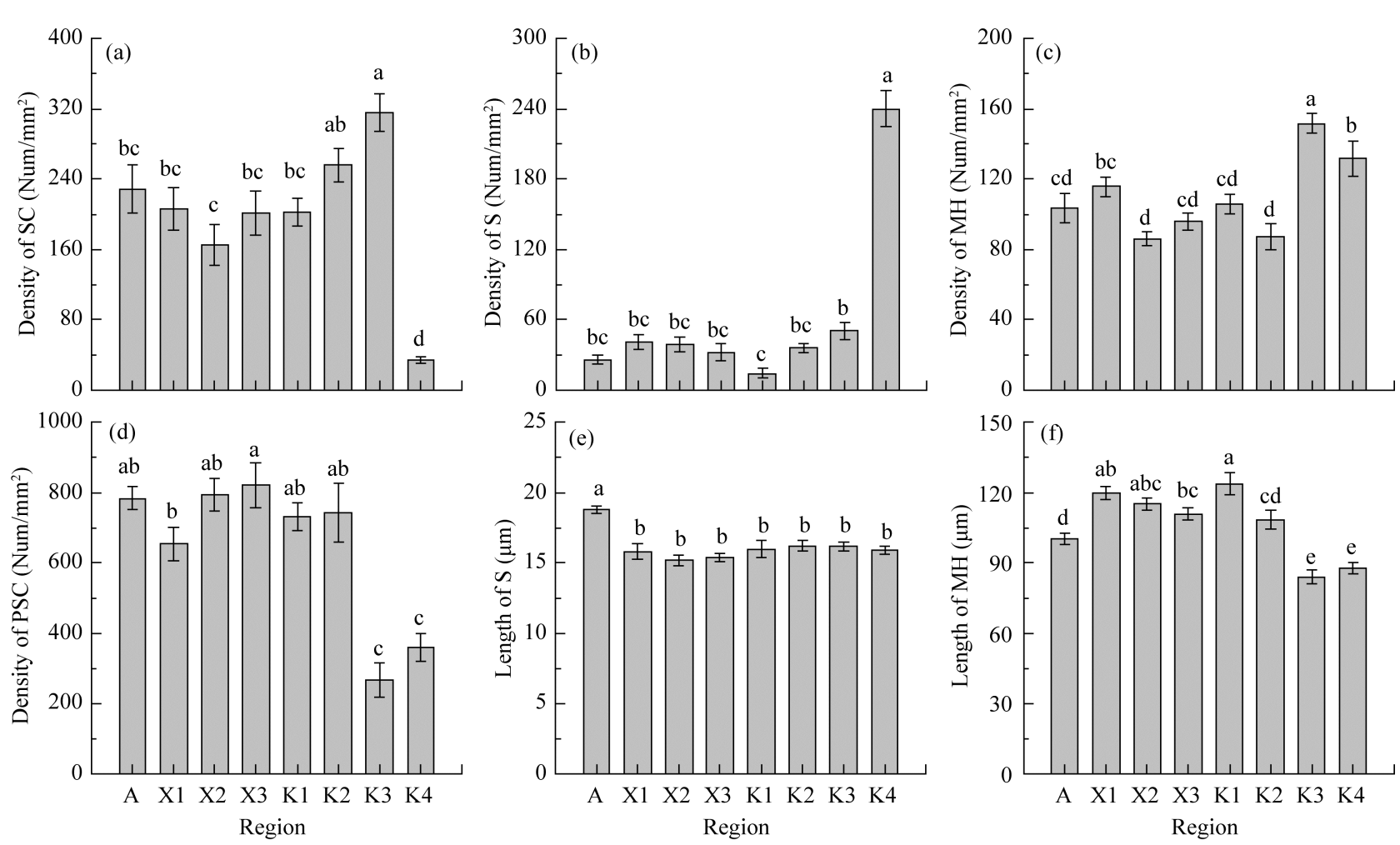

Fig. 10 Density of different types of cells in the transition area of the lemma. Abbreviations: MiH, microhair; S, stomata; $\mathrm{MH}$, macrohair; PSC, papillary short cell.
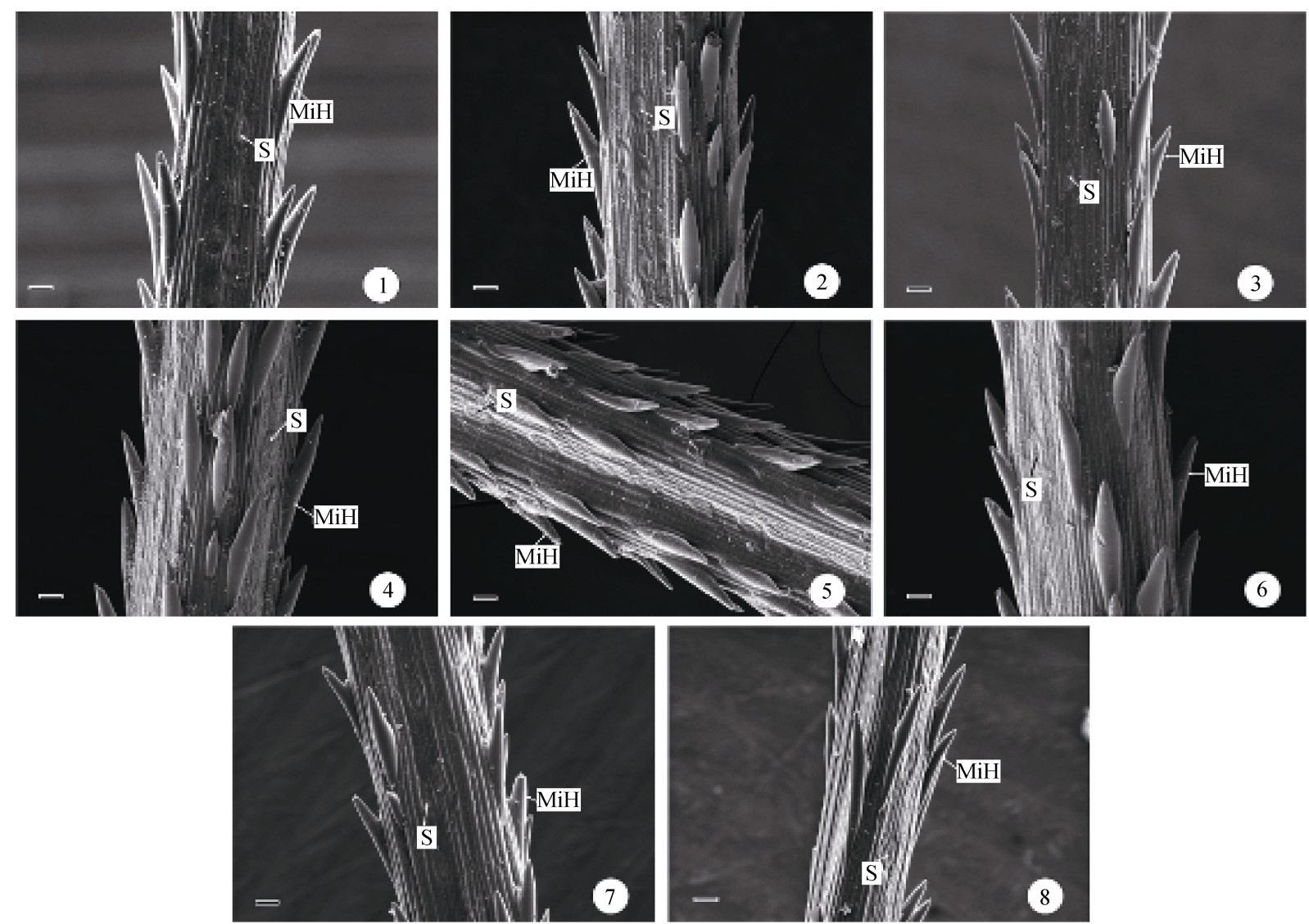

Fig. 11 Micromorphological characteristics of the central awn $(\mathrm{scale}=20 \mu \mathrm{m})$. Abbreviations: $\mathrm{MiH}$, microhair; $\mathrm{S}$, stomata. 

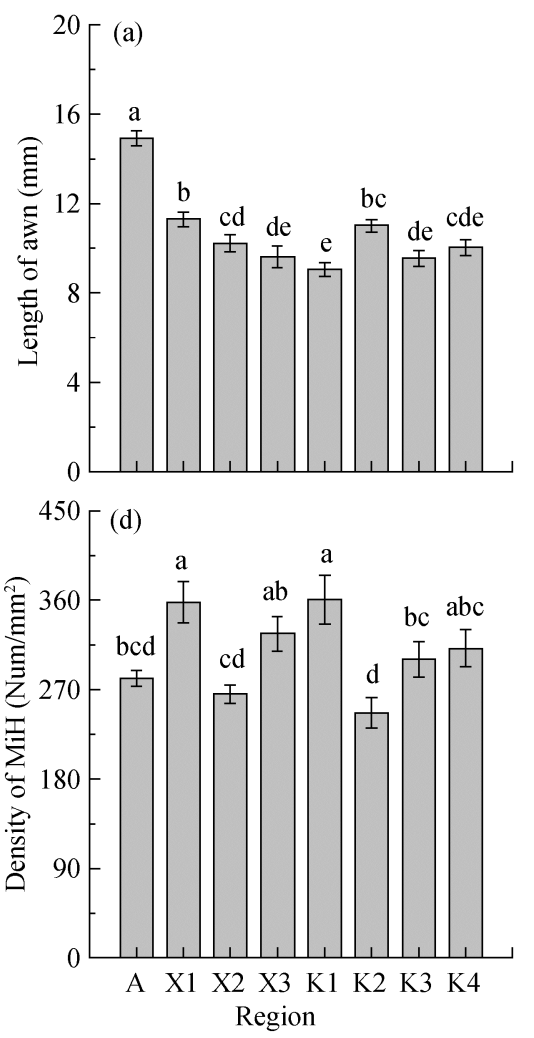
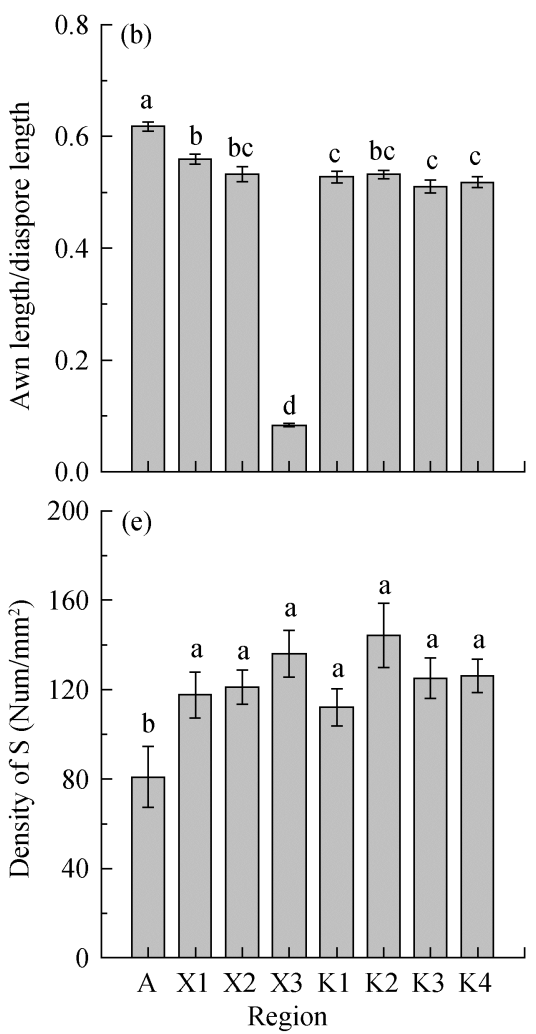
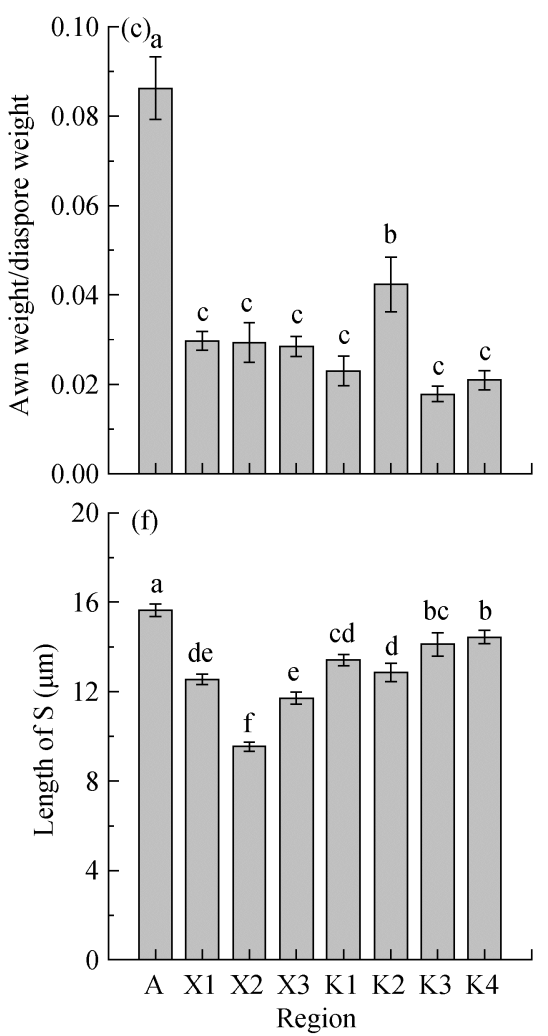

Fig. 12 The density and length of different types of cells in the middle of the Awn. Abbreviations: MiH, microhair; S, stomata.

tion of diaspores to drought conditions. Both the $\mathrm{K} 3$ and $\mathrm{K} 4$ seed collection locations are in the Taukum Desert, Kazakhstan, where average temperature of July reaches $29^{\circ} \mathrm{C}$ and mean annual precipitation is less than $100 \mathrm{~mm}$ (Bekenov et al., 2001). In contrast, the layers that cover diaspores from Great Basin are thinner; we can infer these thinner covering layers may contribute to an easy penetration for the radicle, Debeaujon et al. (2000) suggested it can provide an advantage in seedling establishment. Furthermore, diaspores from $\mathrm{A}$ are also larger than those from other regions (Fig. 2), and larger seeds coupled with thinner protective layers suggest greater allocation to storage of energy reserves in seeds, which in turn may contribute to the evolution of increased competitive ability in invasive plants in general (Blossey et al., 1995) and to cheatgrass in particular (Stewart et al., 1949; Melgoza et al., 1990).

The characteristics of the base of diaspores influence seed germination, seedling settlement, and successful establishment (Peart, 1984). From Fig. 6, we can see the length and density of prickles on the basal part of the lemma from the Great Basin are greater, which may increases adhesive dispersal of diaspores through animals (Leishman (2000) mentioned this in his investigation). In addition, antrorse (backwardly directed) bristles or barbs at the base of seeds act as spring-loaded barbs that firmly anchor diaspores to the soil, thus opposing the force produced by the radicle penetrating the soil (Peart, 1984; Chambers et al., 1994). Thus, this antrorse characteristic also provides an advantage during seed germination by providing good soil-seed and soil-radicle contact, which reduces mortality from desiccation during seedling establishment.

Diaspores from K3 and K4 had higher density of prickles in the transition area between the lemma and awn. However, diaspores from K3 and K4 were shorter, which might be caused by high silicon deposition, which limits transpiration. Thus, the length of the macrohair is limited. The collapsed long epidermal cell in the middle lemma also exhibits higher density (Fig. 7b). Sangster (1983) determined that silicification occurs in a rapid, basipetal sequence as epidermal maturation proceeds. The presented experimental data support the result of a previous study that silicon 
deposition moves to the middle part of the lemma when transpiration is limited. Polymerization of the silica in the middle part of the lemma of the diaspores from X1, X2, X3, K1, and K2 was weaker compared with those from the other regions with longer macrohair in the transition area. Thus, the mode of silicon deposition is influenced by the lack of transpirational pull due to lack of moisture. Martin (1997) cited that environmental factors affect the large amount of silica accumulated by caryopsis. Environmental factors also influence the amount of water and silica being distributed to different parts of the caryopsis, meanwhile, the content of silica deposition can reflect the change of environment to some extent (Hodson et al., 1982; Parry et al., 1982; Takahashi et al., 2008). Moreover, the density of the papillary short cell in the transition area decreases as the densities of the SC and MH increase (Fig. 9). PR and SC are two types of cells used in silicon deposition (Kaufman et al., 1985).

There are great differences in mean monthly temperature and precipitation in Great Basin and Yili Valley. In Great Basin, cheatgrass seeds ripened during the late spring and summer, and the transpiration on the lemma is not very intense due to the moderate temperature (less than $20^{\circ} \mathrm{C}$ ) during the maturation, the deposition of silica on trichomes and long epidermal cell wall exhibited a normal process. Whereas in Yili Valley (X1, X2, X3), it was hot and rainy during the same period, the density of CLC in the middle part of lemma was lesser for the reason that the deposition of silica could not limit the trichomes. However in Taukum Desert (see Fig. 1), the situation was completely different, the high temperature and low rainfall made the process shifted, the silicified trichome in the transition area of the lemma might limit the further lose of water, as a result, the water loss site transferred to the middle part of the lemma, and finally the amount of collapsed long epidermal cell increased (Fig. 7). Moreover, the density of CLC in the middle of lemma from $\mathrm{K} 4$ was higher than the other regions (Fig. 8b).

From Figs. 12b and c, we can see ratios of awn length/diaspore length and awn weight/diaspore weight for diaspores from the Great Basin were significantly greater than those from Central Asia. From what we can inferred that the longer awn can provide some advantages for the positioning of the diaspore, some results show awns contribute about $10 \%$ of carbohydrates to grain (Blum, 1985; Jiang et al., 2006). Awns also continue producing photosynthetic products even after metabolic activity of leaves completely ceases (Ponzi et al., 2005). Hence, the longer awn of diaspores from Great Basin might contribute more photosynthetic products compared with those from Central Asia. In addition, long, rigid awns act as anchors when diaspores are dispersed (Young and Allen, 1997). Awn length is significantly and positively correlated with seed burial depth (Garnier et al., 2001), and Garnier et al. (2001) noted the potential role of high-fire density in selecting diaspores with longer awn length. Fire is a common phenomenon in $B$. tectorum-dominated areas within the Great Basin (Pellant, 1990; Whisenant, 1990; Link et al., 2006). Thus, increased awn length in the Great Basin likely reflects in part an adaptation to high fire frequency.

\section{Conclusions}

The comparison of diaspore characteristics from the United States and Central Asia indicated that morphological characteristics of the diaspores from the United States differed in ways to increase establishment potential, and hence competitive ability, of diaspores in areas where $B$. tectorum is invasive. However, increased allocation of resources to characteristics that increase establishment potential appears to have a trade-off: increased allocation to diaspore establishment ability appears to come at the cost of reduced ability to reduce water loss and resist pests. These results fit the EICA hypothesis of invasive species partially. Finally, the results of this study are consistent with the hypothesis that the density of silica cells is not greatly influenced by environmental factors but may be genetically controlled. The densities of PR, $\mathrm{MH}$, and CLC on the lemma are easily influenced by environmental factors such as temperature and moisture.

\section{Acknowledgements}

This study was supported by the International Science and Technology Cooperation Program of China (2010DFA9272006), with partial support to RSN from the US National Science 
Foundation (1047575) and the Nevada Agricultural Experiment Station. I would like to thank the scanning electron microscopy laboratory of the Xinjiang Institute of Ecology and Geography, Chinese Academy of Sciences for providing the experimental facilities. The assistance from XiaoBing ZHOU, Jing ZHANG, Lin WU, and Ye TAO is gratefully acknowledged. I would also like to thank Hui YIN who assisted the author with SEM and photography during the study.

\section{References}

Beckstead J, Meyer S E, Molder C J, et al. 2007. A race for survival: can Bromus tectorum seeds escape Pyrenophora semeniperda-caused mortality by germinating quickly? Annals of Botany, 99(5): 907-914.

Bekenov A, Blank D, Grachev Y A, et al. 2001. Kazakhstan. Antelopes. Part 4: North Africa, the Middle East, and Asia. Global Survey and Regional Action Plans, 134.

Black J. 1958. Competition between plants of different initial seed sizes in swards of subterranean clover (Trifolium subterraneum L.) with particular reference to leaf area and the light microclimate. Australian Journal of Agricultural Research, 9(3): 299-318.

Blossey B, Notzold R. 1995. Evolution of increased competitive ability in invasive nonindigenous plants: a hypothesis. Journal of Ecology, 83(5): 887-889.

Blum A. 1985. Photosynthesis and transpiration in leaves and ears of wheat and barley varieties. Journal of Experimental Botany, 36(3): $432-440$

Caldwell M M, Eissenstat D M, Richards J H, et al. 1985. Competition for phosphorus: differential uptake from dual-isotope-labeled soil interspaces between shrub and grass. Science, 229(4711): 384-386.

Challaiah, Burnside O C, Wicks G A, et al. 1986. Competition between winter wheat (Triticum aestivum) cultivars and downy brome (Bromus tectorum). Weed Science, 34(5): 689-693.

Chambers J C, MacMahon J A. 1994. A day in the life of a seed: movements and fates of seeds and their implications for natural and managed systems. Annual Review of Ecology and Systematics, 25: 263-292.

Chambers J C. 1995. Relationships between seed fates and seedling establishment in an alpine ecosystem. Ecology, 76(7): 2124-2133.

Debeaujon I, Léon-Kloosterziel K M, Koornneef M. 2000. Influence of the testa on seed dormancy, germination, and longevity in Arabidopsis. Plant Physiology, 122(2): 403-414.

Decker H F. 1964. An anatomic-systematic study of the classical tribe Festuceae (Gramineae). American Journal of Botany, 51(4): 453-463.

Drake J M. 2004. Allee effects and the risk of biological invasion. Risk Analysis, 24(4): 795-802.

Ellis R P. 1979. A procedure for standardizing comparative leaf anatomy in the Poaceae. II . the epidermis as seen in surface view. Bothalia, 12: 641-671.
Evans L, Rawson H M. 1970. Photosynthesis and respiration by the flag leaf and components of the ear during grain development in wheat. Australian Journal of Biological Sciences, 23(2): 245-254.

Evans R A, Young J A. 1987. Seedbed microenvironment, seedling recruitment, and plant establishment on rangelands. In: Frasier G W, Evans R A. Seed and Seedbed Ecology of Rangeland Plants. Tucson: USDA-Agricultural Research Service, 212-220.

Fenner M. 1980. The inhibition of germination of Bidens pilosa seeds by leaf canopy shade in some natural vegetation types. New Phytologist, 84(1): 95-101.

Garnier L K M, Dajoz I. 2001. Evolutionary significance of awn length variation in a clonal grass of fire-prone savannas. Ecology, 82(6): 1720-1733.

Harper J L, Lovell P, Moore K. 1970. The shapes and sizes of seeds. Annual Review of Ecology and Systematics, 1: 327-356.

Hodson M, Sangster A, Parry D W. 1982. Silicon deposition in the inflorescence bristles and macrohairs of Setaria italica (L.) Beauv. Annals of Botany, 50(6): 843-850.

Hull A. 1963. Competition and water requirements of cheatgrass and wheatgrasses in the greenhouse. Journal of Range Management, 16(4): 199-204.

Jacobs S. 2001. The genus Lachnagrostis (Gramineae) in Australia. Telopea, 9(3): 439-448.

Jiang Q, Roche D, Durham S, et al. 2006. Awn contribution to gas exchanges of barley ears. Photosynthetica, 44(4): 536-541.

Kaufman P B, LaCroix J D, Rosen J J, et al. 1972. Scanning electron microscopy and electron microprobe analysis of silicification patterns in inflorescence bracts of Avena sativa. American Journal of Botany, 59(10): 1018-1025.

Kaufman P B, Dayanandan P, Franklin C, et al. 1985. Structure and function of silica bodies in the epidermal system of grass shoots. Annals of Botany, 55(4): 487-507.

Klemmedson J O, Smith J G. 1964. Cheatgrass (Bromus tectorum L.). The Botanical Review, 30(2): 226-262.

Kumar D, Rangaswamy N. 1984. SEM studies on seed surface of wild and cultivated species of Vigna Savi. Indian Academy of Sciences, 93(1): 35-42.

Leger E A, Espeland E K, Merrill K R, et al. 2009. Genetic variation and local adaptation at a cheatgrass (Bromus tectorum) invasion edge in western Nevada. Molecular Ecology, 18(21): 4366-4379.

Leishman M R, Wright I J, Moles A T, et al. 2000. The evolutionary ecology of seed size. Seeds: the Ecology of Regeneration in Plant Communities, $2^{\text {nd }}$ ed. New York: CABI Publishing, 31-57.

Link S O, Keeler C W, Hill R W, et al. 2006. Bromus tectorum cover mapping and fire risk. International Journal of Wildland Fire, 15(1): 113-119.

Ma J, Li J Z, Chao Z, et al. 2003. A study on microstructural feature of the seeds of desert plants in northwest China. Journal of Zhejiang Normal University: Natural Science, 26(2): 109-115.

Martin A, Benayas J. 1997. Silica deposition in the inflorescence bracts 
and caryopsis of Gramineae of Central Spain. Primer Encuentro Europeo sobre el Estudio de Fitolitos: first European Meeting on phytolith Research. Madrid: CSIC, 146-158.

Melgoza G, Nowak R S, Tausch R J. 1990. Soil water exploitation after fire: competition between Bromus tectorum (cheatgrass) and two native species. Oecologia, 83(1): 7-13.

Melgoza G, Nowak R S. 1991. Competition between cheatgrass and two native species after fire: implications from observations and measurements of root distribution. Journal of Range Management, 44(1): 27-33.

Meyer S E, Allen P S, Beckstead J. 1997. Seed germination regulation in Bromus tectorum (Poaceae) and its ecological significance. Oikos, 78(3): 475-485.

Meyer S E, Allen P S. 1999. Ecological genetics of seed germination regulation in Bromus tectorum L. Oecologia, 120(1): 27-34.

Ortúñez E, de la Fuente V. 2010. Epidermal micromorphology of the genus Festuca L. (Poaceae) in the Iberian Peninsula. Plant Systematics and Evolution, 284(3): 201-218.

Parry D W, Hodson M. 1982. Silica distribution in the caryopsis and inflorescence bracts of foxtail millet [Setaria italica (L.) Beauv.] and its possible significance in carcinogenesis. Annals of Botany, 49(4): 531-540.

Peart M H. 1984. The effects of morphology, orientation and position of grass diaspores on seedling survival. The Journal of Ecology, 72(2): 437-453.

Pellant M. 1990. The cheatgrass-wildfire cycle-are there any solutions? General Technical Report-Intermountain Research Station, USDA Forest Service, INT-276, INT-276: 11-18.

Ponzi R, Pizzolongo G. 2005. Cytological and anatomical observations on the awn and lemma of wheat (Triticum aestivum L. cv. Ofanto). Plant Biosystems-An International Journal Dealing with all Aspects of Plant Biology, 139(3): 345-348.

Ray-Mukherjee J, Jones T A, Adler P B, et al. 2011. Immature seedling growth of two North American native perennial bunchgrasses and the invasive grass Bromus tectorum. Rangeland Ecology \& Management, 64(4): 358-365.

Rice K J, Dyer A R. 2001. Seed aging, delayed germination and reduced competitive ability in Bromus tectorum. Plant Ecology, 155(2): 237-243.
Sangster A, Hodson M, Parry D. 1983. Silicon deposition and anatomical studies in the inflorescence bracts of four Phalaris species with their possible relevance to carcinogenesis. New Phytologist, 93(1): 105-122.

Shu P, Zhong W Y. 1990. A systematic and evolutionary study of Zizania L. (Gramineae) epidermal features of Pistillate lemma. Guihaia, 10(2): 107.

Stewart G, Hull A. 1949. Cheatgrass (Bromus tectorum L.) -an ecologic intruder in southern Idaho. Ecology, 30(1): 58-74.

Takahashi N, Isogai A, Ling P, et al. 2008. Effects of elevated atmospheric carbon dioxide concentration on silica deposition in rice (Oryza sativa L.) panicle. Plant Production Science, 11(3): 307-315.

Whisenant S G. 1990. Changing fire frequencies on Idaho's Snake River Plains: ecological and management implications. General Technical Report-Intermountain Research Station, USDA Forest Service, INT-276, INT-276: 4-10.

Wicks G A. 1984. Integrated systems for control and management of downy brome (Bromus tectorum) in cropland. Weed Science, 32(1): 26-31.

Xie X M, Yun J F, Gao Y C, et al. 2002. Variation patterns on micro-morphological characteristics of lemmas of Agropyron Mongolicum. Bulletin of Botanical Research, 22(2): 168-174.

Yang F J, Zhang Z H, Wang W J, et al. 2007. Anatomical and physiological diferences of eight exotic species from Asteraceae. Acta Ecologica Sinica, 27(2): 442-449.

Young J A, Allen F L. 1997. Cheatgrass and range science: 1930-1950. Journal of Range Management, 50(5): 530-535.

Zhang J G, Duan A G, Zhang J P, et al. 2006. A study on seed characteristics of large berry cultivars of sea buckthorn. Forest Research, 19(6): 700-705.

Zhang X Q, Zhou F, Xie X M. 2010. Lemma micro-morphological characteristics of MT-1 elephant grass and its closely related varieties. Acta Prataculturae Sinica, 19(4):159-165.

Zhou Y. 2003. Preliminary study on geographic populations of Trigonobalanus doichangensis and its effect on seed germination and seedling. Seed, 4: 3-4.

Zhu Z H. 1992. Root length, leaf area and biomass of Agropyron desertorum and Bromus tectorum. Grassland and Turf, 1(1): 31-33. 